\title{
Anti-quality components in forage: Overview, significance, and economic impact ${ }^{1}$
}

\author{
VIVIEN GORE ALLEN AND EDUARDO SEGARRA
}

Authors are Thornton Distinguished Chair, Department of Plant and Soil Science, and professor, Department of Agricultural and Applied Economics, Texas Tech University, Lubbock. Tex. 79409-2122.

\begin{abstract}
Although recognized in importance from the dawn of history, forages have too often been underestimated and undervalued perhaps in part because animal performance has frequently failed to reflect apparent forage quality. Anti-quality components, diverse impediments to quality, have evolved as structural components and as secondary metabolites. They include mineral imbalances or can be related to the presence of insects and diseases. Animal behavior and adaptation are increasingly recognized as important aspects of anti-quality factors. An anti-quality component may reduce dry matter intake, dry matter digestibility, or result in nutritional imbalances in animals. They can act as a direct poison compromising vital systems, result in abnormal reproduction, endocrine function, and genetic aberrations, trigger undesirable behavior responses, or suppress immune function leading to increased morbidity and mortality. The economic impact of anti-quality factors on individual herds can be devastating but definable. Broadscale economic impacts of anti-quality factors are far more difficult to estimate. A loss of $0.22 \mathrm{~kg} / \mathrm{day}$ in potential gain of stocker cattle due to antiquality factors during a 166-day grazing season translates into a loss of about $\$ 55 /$ steer at $\$ 1.45 / \mathrm{kg}$ or over $\$ 2$ billion annually when applied to the U.S stocker cattle. Economic losses to tall fescue (Festuca arundinacea Schreb.) toxicosis in the U.S. beef industry are probably underestimated at $\$ 600$ million annually. Reproductive and death losses of livestock due to poisonous plants have been estimated at \$340 million in the 17 western states alone. These examples of economic losses due to anti-quality factors may be upper bounds of actual losses but even if a small proportion of the expected losses were eliminated through research, the potential payoff would be extremely high.
\end{abstract}

Key Words: nutrition, animal health, performance, forage quality, toxins

${ }^{1}$ Appreciation is expressed to Karen Launchbaugh, Univ. of Idaho and the Society for Range Management and Rosa Muchovej, Univ. of Florida and American Forage and Grassland Council who organized this symposium and cochaired this event. Appreciation is also express to Richard Joost who has served as the senior editor for the publications resulting from this symposium. The USDANatural Resource Conservation Service (NRCS) provided financial support for this symposium and for the resulting publications. Without the support of the NRCS, this symposium would not have been possible.

Manuscript accepted 14 Jan. 01.

\section{Resumen}

Aunque su importancia se reconoce desde las épocas tempranas de la historia, los forrajes también frecuentemente han sido subestimados y subvaluados, en parte porque a menudo el comportamiento productivo del animal ha fallado en reflejar la calidad aparente del forraje. Los compuestos anti-calidad, obstáculos variados de la calidad, han evolucionado como componentes estructurales y metabolitos secundarios. Ellos incluyen desbalances minerales o pueden ser relacionados a la presencia de insectos o enfermedades. El comportamiento animal y la adaptación se reconocen mas y mas como aspectos importantes de los factores anti-calidad. Un componentes anti-calidad puede reducir el consumo de materia seca, la digestibilidad de la materia seca o producir en los animales desbalances nutricionales. Ellos pueden actuar directamente como veneno dañando sistemas vitales, producir una reproducción anormal, problemas endocrinológicos, aberraciones genéticas desencadenar respuestas de comportamiento indeseable o suprimir la función inmune incrementando la morbilidad y mortalidad. El impacto económico de los factores anti-calidad en los hatos individuales puede ser devastador pero definible. Los impactos a amplia escala de los factores anti-calidad son mas difíciles de estimar. Una perdida de $0.22 \mathrm{~kg} /$ día de la ganancia potencial del ganadero debido a factores anti-calidad durante una época de apacentamiento de 166 días se traduce en una perdida de aproximadamente \$55 dolares/ novillo, a un precio de $\$ 1.45 / \mathrm{kg}$, o de mas de 2 billones anuales si se aplica al total de la ganadería de E.U.A. Las perdidas económicas de la industria del ganado de carne de los E.U.A. por la toxicosis del Alta fescue (Festuca arundinacea Schreb.) son probablemente subestimadas en $\$ 600$ millones anuales. Solo en los 17 estados del oeste, las perdidas por muerte y reproducción del ganado debido a plantas tóxicas han sido estimadas en \$ 340 millones. Estos ejemplos de perdidas económicas debido a los factores anti-calidad pueden ser los limites superiores de las perdidas actuales, pero aun si una pequeña proporción de las perdidas esperadas fuera eliminada a través de investigación, el pago por estas perdidas sería extremadamente alto.

\section{Overview and Significance}

The importance of forages has echoed through the ages. The value of forages was recognized from the early dawn of history as animals became domesticated and were moved from place to place in search of forage (Combs 1936). Alfalfa is thought to have been cultivated before the development of the written lan- 
guage (Bolton et al. 1972). During the settlement years in the U.S., the value of forages went largely unrecognized with forages frequently relegated to lands of marginal arable value (Edwards 1948). Often, there was little recognition of differences in value among forage species. This sentiment began to change as P. V. Cardon stated in the 1948 Yearbook of Agriculture, "..., in the wake of war and in the glow of our unprecedented production, this country looks to the future and considers again the land and its management this time, as never before, in terms of grass." (Cardon 1948). In his preface to Forages: Resouces for the Future, Burton (1986) states "Forages, particularly the grasses, are the most important plants on the face of the earth". Occupying more than half the land area in the U.S. and world wide, forages provide about three fourths of the energy and more than half of the protein in human diets (Burton 1986). Because ruminants and equine obtain 60 to $100 \%$ of their feed nutrients from forages and because of the economic importance of forage consuming livestock and wildlife, the value of forage rivals that of the most important field crops. For too long the nutritional and economic value of forages has been underestimated and under-recognized.

As the human population increases, land areas suitable for intensive crop production decrease, and issues of renewable resource conservation become more compelling. As Cardon (1948) stated over a half century ago, “... around grass, farmers can organize general crop production so as to promote efficient practices that lead to permanency in agriculture."

Quality of forage is paramount in obtaining optimum animal performance. Any factor or 'anti-quality component' that prevents forage from contributing its nutritional potential takes on added importance with increased recognition of forage as a feed resource. During recent years, much progress has been made in several areas perhaps most dramatically in elucidating the etiology of tall fescue (Festuca arundinacea Schreb.) toxicosis and its relationship to the endophyte fungus Neotyphodium coenphialum [(MorganJones and Gams) Glenn, Bacon, and Hanlin; Glenn et al. 1996]. Advances have also been made in identifying specific toxins, and physical and chemical factors that affect intake and digestibility. The role of animal behavior in avoidance of anti-quality factors has great potential and is the subject of a paper presented in this symposium.
There has always been concern that antiquality components in forages have the potential to compromise food safety and human health. Ergotism in humans consuming wheat (Triticum aestivum L.), rye (Secale cereale L.), pearlmillet [Pennisetum americanum (L.) Leeke], and other small grains contaminated with Claviceps species has been documented both historically and during modern times (Krishnamachari and Bhat 1976, Lewis 1977) Humans can potentially be exposed to several mycotoxins by direct consumption of grains contaminated with products of fungal growth although strict control of food quality on the U.S. market makes this unlikely to occur (CAST 1989, Wood 1992). However, possible long-term exposure to low levels of mycotoxins in the food supply is of potential concern. Human consumption of animal products affected by anti-quality factors is also of concern. Ammoniation of hay has been related to hyperexcitability in cattle (i.e. Crazy Cow Syndrome) and high death losses of calves either at birth or within a few days of birth (Essig et al. 1986). A case study in Mississippi suggested that milk from a cow fed ammoniated hay could produce symptoms of hyperexcitability in a nonrelated calf fed the milk (Essig et al. 1986) raising concerns about milk safety for humans. In the U.S., it is unlikely that lactating dairy cows would be fed ammoniated hay but this could occur in other parts of the world.

The subject of anti-quality factors is far reaching and includes pastures and harvested forages as well as rangelands and grazeable forestlands. The following papers in this volume were part of a symposium held in 1999 on 'Anti-quality Components in Forages' at the joint meeting of the Society for Range Management and the American Forage and Grassland Council. It is hoped that this symposium helped to synthesize the current state of knowledge and to present the information in written format that will serve as a reference for the industry. The subject of antiquality factors will continue to evolve as new information is generated and this is indeed a topic that will need to be revisited in the future.

\section{What is Forage Quality and Anti-quality?}

It is necessary to clearly understand what forage quality is before we can begin to address its' antithesis, antiquality. In his review of 'Milestones in Forage Research,' Reid (1994) concluded that forage quality was definable as "some product of digestibility and intake of the diet." Mott and Moore (1969) described forage quality as composed of both 'forage nutritive value' (chemical composition, digestibility, and nature of digested products) and 'forage consumed' (acceptability, rate of passage, and availability). Raymond (1968) suggested that quality is defined by the equation 'Nutrient intake $=$ intake of feed dry matter $x$ digestibility of feed dry matter $x$ efficiency of utilization of digested nutrients'. More general definitions of forage quality include "Characteristics that make forage valuable to animals as a source of nutrients; the combination of chemical and biocharacteristics of forage that determines its potential to produce meat, milk, wool, or work" (Barnes and Beard 1992, Barnes et al. 1995). Ball et al. (1991) suggest that forage quality is best defined in terms of animal performance and that it is ultimately the animal rather than the human that determines forage quality.

Although each of these definitions provides useful mathematical and philosophical concepts regarding forage quality, each one appears to fall short of a succinct definition. Dictionary definitions of 'quality' generally refer to the 'degree of excellence'. Thus, we propose that forage quality is best described as the degree to which a forage meets the nutritional requirements of a specific kind and class of animal. An 'anti-quality component' would, therefore, be defined as any factor that diminishes the degree to which a forage meets the nutritional requirements of a specific kind and class of animal. The word 'animal' is necessary in these definitions to include both 'livestock' and 'wildlife'. Furthermore, it is necessary to specify the kind and class of animal because animal nutritional needs and detoxification abilities vary. A forage that meets the nutritional needs for dry cows would, thus, be a high quality dry cow feed, but may not meet the requirements for finishing steers and would, therefore, be a low quality finishing diet. Likewise, a chemical toxin or a physical inhibitor to intake for 1 species or class of animal may not affect another species or class of animal in a similar manner. Animal behavior and adaptation are increasingly being recognized as important aspects of anti-quality factors. For example, ability of the pregastric fermentor to detoxify many of the potentially harmful plant metabolites has long been recognized. Palatability, rate of 
passage, digestibility, nutrient density and balance, and intake are all factors determining the degree to which the forage is able to meet the nutritional demands of the animal. Therefore, as suggested by Mott and Moore (1969), quality of the forage is going to be driven by the combination of chemical and physical characteristics that determine 'forage nutritive value' and 'intake' and these are terms that should be defined as a subset under the definition of forage quality.

\section{Classes and Kinds of Anti-qual- ity Components}

Anti-quality components encompass a diverse array of unrelated causative agents. These may have evolved as structural components of the plant or as secondary metabolites resulting in plant defense mechanisms. Anti-quality components can be revealed as mineral deficiencies, toxicities, and nutritional imbalances. The origin of anti-quality attributes can be phytochemicals in plant tissues or structural inhibitors in leaf and stem arrangement. Specific chemical inhibitors of quality can result from plant metabolism or from microbial origin. Anti-quality factors in forages can furthermore be related to the presence of insects and diseases.

An anti-quality component may simply act as a reducer of dry matter intake (DMI), may reduce dry matter digestibility, or result in nutritional imbalances. The anti-quality factor may act as a direct toxin that shuts down vital systems in animals, it may result in abnormal reproduction, disturb endocrine or neurological function, cause genetic aberrations, or may suppress immune function leading to increased morbidity and mortality. Because of the many and disrelated syndromes and yet the potential for many interactions and subtle interrelationships, the field of anti-quality factors is both complex and compelling.

\section{Economic Impact of Anti-quality Components}

The economic impact of anti-quality factors on individual flocks and herds can be devastating when the result is a large loss in production, reproduction, morbidity, or mortality. Economic consequences can also be severe if the loss is but a single animal with high economic value. The economic effect is much less obvious when the result is a subtle decrease in potential performance. The economic impact of anti-quality components on animal health and production are often difficult to estimate. Nevertheless, broadscale estimates are needed to provide perspective and to help focus research efforts into areas of high potential economic improvement. Estimates of the impact of diminished forage quality with lowered potential for gain highlight the magnitude of economic impact. An example of this can be derived from calculations using the current beef cattle herd in the U.S. and estimates of expected daily gains based on National Research Council data (NRC 1984).

As of 29 January 1999, there were 16.8 million steers and 19.6 million heifers weighing $227 \mathrm{~kg}$ or more in the U.S. (Agricultural Statistics 1999). The stocker phase of cattle production into which these cattle could be placed, can make efficient use of forage for economical gains. Ball et al. (1991) summerized beef steer performance on 15 forage systems or specific forages in the Southern U.S. and found that daily gains ranged from 0.43 to 1.08 $\mathrm{kg}$ /day during an average 146-day grazing season. Stocker systems in Virginia demonstrated that steers gained 0.90 $\mathrm{kg}$ /day during a 166-day grazing season from April to October in an all forage system (Allen et al. 1994). Estimates based on NRC (1984) requirements for a $227 \mathrm{~kg}$ steer fed to gain $0.90 \mathrm{~kg} /$ day indicate that a dry matter intake (DMI) of $6.26 \mathrm{~kg} /$ day at a given nutritive value is required. If nutritive value is diminished and related DMI declines to $6.08 \mathrm{~kg} /$ day, a decline in intake of $0.18 \mathrm{~kg} / \mathrm{day}$, daily gains would be expected to drop to $0.68 \mathrm{~kg} /$ day. This translates into over 8 million $\mathrm{kg} /$ day loss of potential gain. If a value of $\$ 1.54 / \mathrm{kg}$ is assumed, this results in an approximate cost of $\$ 12.33$ million per day for all stocker cattle in the U.S. or $\$ 0.34 /$ stocker per day. This level of loss of potential gain, represents a total economic loss for the 166-day period of over $\$ 2$ billion. Calculated another way, and again using the Virginia example for steer performance, over the 166-day grazing period, steers gained $151 \mathrm{~kg}$ vs $113 \mathrm{~kg}$ that were gained under the lower quality diet. The 38 $\mathrm{kg}$ difference would be worth about $\$ 55 /$ steer at $\$ 1.45 / \mathrm{kg}$. These levels of economic losses due to the degradation of forage quality could be considered to be an upper bound of the actual level of loss. That is, it would be expected that if stocker producers were to be aware of the potential weight gain losses due to the lower quality of the diet, they might internalize this into their operations to minimize potential loss- es. However, this strategy would result into higher associated cost of production. If the impediments to quality or anti-quality factors were identified and eliminated, it might be more cost effective.

The economic impact of mineral imbalances in forages is often poorly understood. However, hypomagnesic grass tetany has been widely researched. This metabolic deficiency of $\mathrm{Mg}$ has been estimated to result in the loss of 1 to $3 \%$ of the beef cows in the U.S. annually. If the loss is $1 \%$ of the 42.6 million cows and heifers that had calved by 1 January 1999 (Agricultural Statistics 1999), the estimated financial loss to producers would be about $\$ 150$ million assuming a $500 \mathrm{~kg}$ cow worth about $\$ 0.77 / \mathrm{kg}$. Fortunately, $\mathrm{Mg}$ supplementation strategies are available that can largely prevent grass tetany but represent an increase in the cost of production both in terms of added inputs and labor requirements.

Tall fescue (Festuca arundinacea Schreb.) is one of the most important coolseason grasses grown in the U.S. occupying over 14 million ha (Sleper and Buckner 1995). Widely adapted, this longlived perennial forms the basis of many forage-livestock systems. However, much of this fescue is infected with the endophyte-fungus Neotyphodium coenophialum (Shelby and Dalrymple 1987). Presence of the fungus confers stress tolerance to the plant (see review by Latch 1997) but production of alkaloids by both the plant and the fungus result in a myrid of animal disorders (Steudemann and Hoveland 1988). It has been estimated that the endophyte in tall fescue results in loss of over $\$ 600$ million annually to the beef cattle industry alone (Fribourg et al. 1991). Recent evidence suggests that this may be an underestimate. It has been widely accepted that removal of livestock from infected tall fescue pastures resulted in a fairly rapid dissipation of symptoms of tall fescue toxicosis but this now appears not to be the case. Research has shown that one effect of the toxicity is a decline in specific immune function (Saker et al. 1998) during the grazing period. It has now been demonstrated that this loss in immune function is long-lasting, and was measurable throughout the stress of cross country transportation and a following 150-day feedlot finishing period (Saker et al. 2001; Allen et al. 2001). The lowered immunity is likely to contribute to added costs of medications and labor in treating animals that are lesstolerant to stress and disease (Purdy et al. 1989). 
Poisonous plants occur in all types of grazing lands including both range and intensively managed pastureland and are one of the most important economic impediments to profitable livestock production (James et al. 1992). Based on an estimated $1 \%$ death loss in cattle, a $3.5 \%$ death loss in sheep, and a $1 \%$ decrease in calf and lamb crops due to poisonous plants, the economic impact within the 17 western states was estimated at \$340 million annually (Nielsen and James 1991, James et al. 1992). In their review of the impact of poisonous plants on the livestock industry, James et al. (1992) divide economic losses into direct and indirect losses. Direct losses were described to include death, emaciation, slow growth, decreased reproductive efficiency, abortion, and birth defects. Indirect losses included costs incurred to prevent losses or poisoning, medical costs incident to poisoning, losses of forage quality due to need to alter harvesting schedules, stress effects on management, risk, and effects on land values and grazing permits. In addition to their application to poisonous plants, these types of losses should be accounted for in accessing economic consequences of many types of anti-quality factors.

The potential economic losses discussed above, represent only a few of the areas/issues on which anti-quality components have an impact. Even if these areas were to be the only ones affected by antiquality components in forage, the potential associated total economic damage would be over $\$ 3$ billion. At the same time, however, this level of damage provides an estimate of the potential payoff of research addressing the anti-quality components in forage issue. Even if a very small proportion of the expected losses were to be eliminated through research dedicated to minimize the negative impacts of antiquality components in forage, a relatively large research program could be afforded. That is, the potential payoff, i.e. benefitcost ratio, of such a research program would be extremely high. It is hoped that the information presented in this symposium will highlight the need and provide the impetus for further research and the dedication of funding sources to support this research for forages are the key to economical production of ruminants and equine and are central to the protection of our natural resources. Forages ARE the most important plants on earth and impediments to their potential as a feed source take on parallel importance.

\section{Literature Cited}

Allen, V.G., J.P. Fontenot, and A. Brock. 1994. Forage systems for stocker cattle, p. 156-158. Anim. and Poultry Sci. Res. Rep. No. 11. Virginia Polytechnic Institute and State University, Blacksburg, Va.

Allen, V.G., K.R. Pond, K.E. Saker, J.P. Fontenot, C.P. Bagley, R.L. Ivy, R. Evans, C.P. Brown, T.M. Dettle, M.F. Miller, and J. Montgomery. 2001. Tasco-Forage: III. Influence of a seaweed extract on performance, monocyte immune cell response, and carcass characteristics in feedlot-finished steers. J. Anim. Sci. 79:1032-1040.

Agricultural Statistics. 1999. USDA-NASS, U.S. Gov. Printing Office, Washington, D.C.

Ball, D.M., C.S. Hoveland, and G.D. Lacefield. 1991. Southern forages. Potash \& Phosphate Inst. and Foundation Agron. Res. Atlanta, Ga.

Barnes, R.F and J.B. Beard (ed.). 1992. A glossary of crop science terms. Crop Sci. Soc. Amer. Madison, Wis.

Barnes, R.F, D.A. Miller, and C.J. Nelson (ed.). 1995. Forages: an introduction to grassland agriculture. Vol. I. Iowa State Univ. Press, Ames, Iowa.

Bolton, J.L., B.P. Goplen, and H. Baenziger. 1972. World distribution and historical developments, p.1-34. In: C.H. Hanson (ed.), Alfalfa Science and Technology. No. 15. Amer. Soc. Agron. Madison, Wis.

Burton, G.W. 1986. Preface. In: Forages: Resources for the future. Counc. Agr. Sci. Tech. Rep. 108. Ames, Iowa.

Cardon, P.V. 1948. A permanent agriculture, $p$ 1-5. In: A. Stefferud (ed.),. Grass. The yearbook of agriculture. USDA, U.S. Gov. Printing Office, Washington, D.C.

CAST. 1989. Mycotoxins: economic and health risks. Counc. Agr. Sci. Tech. Rep. 116. Ames, Iowa.

Combs, J.F. 1936. Growing pastures in the south, p. 2. Univ. North Carolina Press, Chapel Hill, N.C.

Edwards, E.E. 1948. The settlement of grasslands, p. 16-25. In: A. Stefferud (ed.), Grass. The yearbook of agriculture. USDA, U.S. Gov. Printing Office, Washington, D.C.

Essig, H.W., E.G. Morrison, H.D. Palmertree, R.R. Evans, D.H. Laughlin, C.E. Cantrell, R. White, R.L. Ivy, and R. Gebhart. 1986. Ammoniated hay for cow wintering diets. Bull. 949. Mississippi Agr. Forest. Exp. Sta. Mississippi State, Miss.

Glenn, A.E., C.W. Bacon, R. Price, and R.T. Hanlin. 1996. Molecular phylogeny of Acremonium and its taxonomic implications. Mycologia 88:369-383.

Fribourg, H.A., K.D. Gwinn, A.B. Chestnut, J.W. Oliver, J.C. Waller, J.H. Reynolds, and B.V. Conger. 1991. Tall fescue and the fungal endophyte. Tennessee Farm Home Sci. 160:10-29.

James, L.F., D.B. Nielsen, and K.E. Panter. 1992. Impact of poisonous plants on the livestock industry. J. Range Manage. 45:3-8.
Krishnamachari, K.A.V.R. and R.V. Bhat. 1976. Poisoning of ergoty bajra (pearl millet) in man. Indian J. Med. Res. 64:1624-1628.

Latch, G.C.M. 1997. An overview of neotyphodium-grass interactions, p. 1-11. In: C.W. Bacon and N.S. Hill (ed.), Neotyphodium/Grass Interactions. Plenum Press, New York, N.Y.

Lewis, W.H. (ed.). 1977. Medical botany, p. 416-418. John Wiley \& Sons, New York, N.Y.

Mott, G.O., and J.E. Moore. 1969. Forage evaluation techniques in perspective. p. L-1 to L-7. In: R.F Barnes, D.C. Clanton, C.H. Gordon, T.J. Klopfenstein, and D.R. Waldo (ed.), Proc. Natl. Conf. Forage Quality Evaluation and Utilization. Nebraska Center Cont. Educ. Lincoln, Neb.

Nielsen, D.B. and L.F. James. 1991. Poisonous plants - Proc. 3rd Int. Symp., Iowa State Univ. Press, Ames.

NRC. 1984. Nutrient requirements of beef cattle ( $7^{\text {th }}$ ed.). National Academy Press, Washington, D.C.

Purdy, C.W., N.A. Cole, and J.A. Stuedemann. 1989. The effect of fescue toxicosis on classical complement in yearling feedlot steers. J. Vet. Diagn. Invest. 1:87-89.

Raymond, W.F. 1968. Components in the nutritive value of forages, p. 47-62. In: C.M. Harrison, M. Stelly, and S.A. Breth (ed.), Forage economics-quality. Amer. Soc. Agron., Madison, Wis.

Reid, R.L. 1994. Milestones in forage research (1969-1994), p. 1-58. In: G.C. Fahey, Jr. (ed.), Forage quality, evaluation, and utilization. Amer. Soc. Agron., Madison, Wis.

Saker, K.E., V.G. Allen, J. Kalnitsky, C.D. Thatcher, W.S. Swecker Jr., and J.P. Fontenot. 1998. Monocyte immune cell response and copper status in beef steers that grazed endophyte-infected tall fescue. J. Anim. Sci. 76:2694-2700.

Saker, K.E., V.G. Allen, J.P. Fontenot, P. Bagley, R. Ivy, and R. Evans. 2001. TascoForage: II. Monocyte immune cell response and performance of beef steers grazing tall fescue treated with a seaweed extract. J. Anim. Sci. 79:1022-1031.

Shelby, R.A. and L.W. Dalrymple. 1987. Incidence and distribuion of the tall fescue endophyte in the United States. Plant Disease 71:783-786.

Sleper, D.A. and R.C. Buckner. 1995. The fescues, p. 345-356. In: R.F Barnes, D.A. Miller, and C.J. Nelson (ed.), Forages: an introduction to grassland agriculture. Vol. I. Iowa State Univ. Press, Ames, Iowa.

Steudemann, J.A., and C.S. Hoveland. 1988. Fescue endophyte history and impact on animal agriculture. J. Prod. Agr. 1:39-44.

Wood, G.E. 1992. Mycotoxins in foods and feeds in the United States. J. Anim. Sci. 70:3941-3949. 